\title{
Group A streptococci in children with acute pharyngitis in Sousse, Tunisia
}

R. Mzoughi, ${ }^{1}$ O. Bouallègue, ${ }^{1}$ H. Selmi, ${ }^{2}$ H. Ben Said,${ }^{3}$ A.S. Essoussi ${ }^{2}$ and M. Jeddi

$$
\begin{aligned}
& \text { العقديات من الزمرة A في الأطفال المصابين بالتهاب البلعوم المحادّ في سوسة، تونس }
\end{aligned}
$$

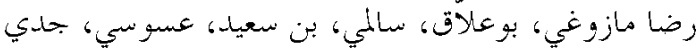

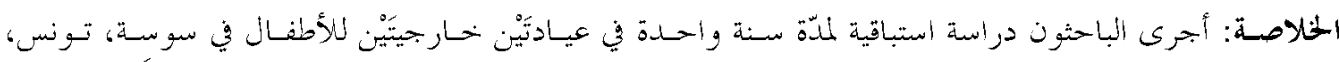

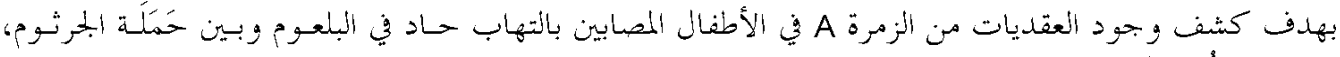

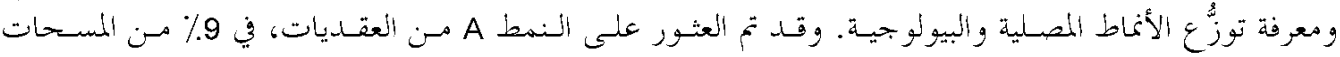

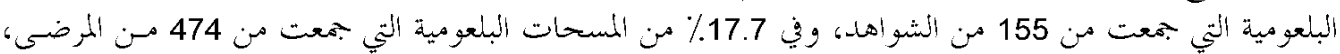

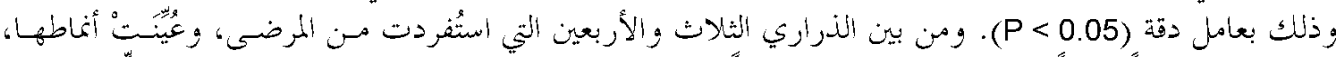

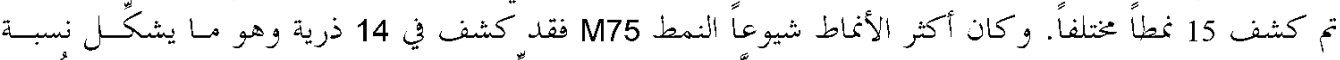

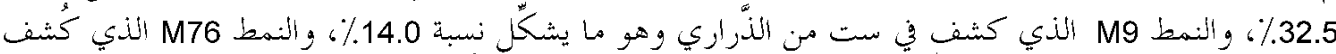

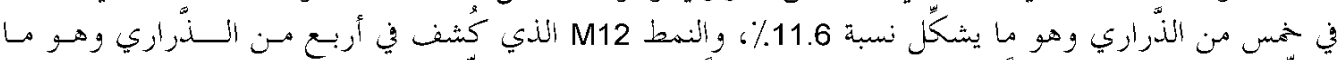

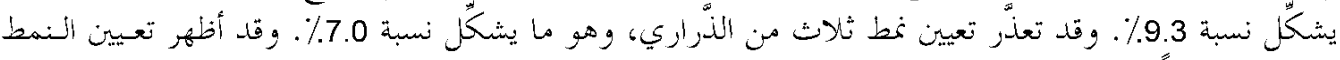

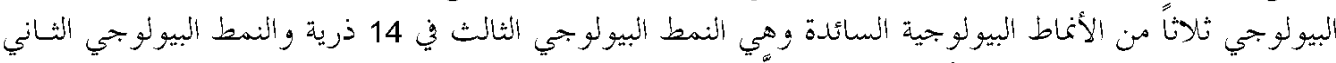

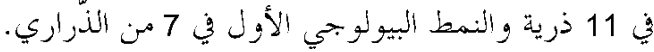

ABSTRACT A 1-year prospective study in 2 paediatric outpatient clinics in Sousse, Tunisia, aimed to determine the presence of group A streptococci in acute pharyngitis cases and carriers, and the distribution of the serotypes and biotypes. Group A streptococci were found in $9.0 \%$ of throat swabs from 155 controls and $17.7 \%$ from 474 patients $(P<0.05)$. Of 43 strains isolated from patients and submitted for typing, 15 different types were identified, the most common being M75 (14 strains; $32.5 \%)$, M9 (6 strains; $14.0 \%)$, M76 (5 strains; $11.6 \%$ ) and M12 (4 strains; 9.3\%). Three strains were non-typeable (7.0\%). Biotyping of the strains showed 3 predominant biotypes: biotype $3(n=14)$, biotype $2(n=11)$, and biotype $1(n=7)$.

Les streptocoques du groupe $A$ chez des enfants atteints de pharyngite aiguë à Sousse (Tunisie) RÉSUMÉ Une étude prospective sur un an réalisée dans deux services de consultations externes pédiatriques à Sousse (Tunisie) avait pour objectif de déterminer la présence de streptocoques du groupe A dans les cas de pharyngite aiguë et chez les porteurs, ainsi que la répartition des sérotypes et biotypes. On a trouvé des streptocoques du groupe $A$ dans $9,0 \%$ des prélèvements de gorge de 155 sujets témoins et chez $17,7 \%$ des 474 patients $(p<0,05)$. Parmi les 43 souches isolées chez les patients et soumises au typage, 15 types différents ont été identifiés, les plus courants étant M75 (14 souches ; 32,5\%), M9 ( 6 souches ; $14,0 \%$ ), M76 (5 souches ; $11,6 \%$ ) et M12 (4 souches ; 9,3\%). Trois souches étaient non typables $(7,0 \%)$. Le biotypage des souches a montré trois biotypes prédominants : le biotype $3(n=14)$, le biotype $2(n=11)$ et le biotype $1(n=7)$.

${ }^{1}$ Microbiology Laboratory; ${ }^{2}$ Paediatric Service, Farhat Hached Hospital, Sousse, Tunisia. ${ }^{3}$ Centre de Protection Maternelle et Infantile (Centre PMI), Erriadh, Sousse, Tunisia. Received: 16/01/03; accepted: 07/10/03

بلملة الصحية لشرق المثوسط، منظمة الصحة العالمية، المجلد العاشر، العددان ع-0، ع + •؟ 


\section{Introduction}

Streptococcus pyogenes (group A streptococcus) is still the most frequent cause of pharyngitis in children and can lead to severe post-infection sequelae including rheumatic fever and glomerulonephritis [1]. The incidence of rheumatic fever has declined rapidly in developed countries where improved living conditions and systematic antibiotic therapy with penicillin have limited the spread of bacterial strains in the population [2-4]. However, unexpected outbreaks of rheumatic fever have occurred in the United States of America [5]. The changing epidemiology of group A streptococci and rheumatic fever is said to be related to changes in the distribution of serotypes [6,7], where certain virulent $M$ types have been associated with invasive disease [5,8-10]. Thus, it is important to establish the epidemiological patterns of group A streptococci in different countries and regions, and especially to serotype the strains that have been isolated. This knowledge will be important for the development and use of vaccines [11].

In Tunisia, rheumatic fever remains an important health problem in children, with an incidence of 57 cases per 100000 inhabitants in 2001 [12]. As a part of the national effort to clarify the epidemiological pattern of group A streptococci in our country the present study was conducted to determine the presence of group A streptococci in acute pharyngitis cases and in carriers in the city of Sousse, and the distribution of serotypes and biotypes.

\section{Methods}

A 1-year prospective study, between 1 October 1994 and 20 September 1995, was conducted in 2 paediatric outpatient clinics in Sousse: Farhat Hached Hospital and Centre de Protection Maternelle et Infantile (Centre PMI) Erriadh. Samples were collected from patients with acute pharyngitis, diagnosed on the basis of fever over $38^{\circ} \mathrm{C}$, sore throat, pharyngeal exudates and acute inflammatory tonsillitis.

A total of 474 patients, age 2 to 8 years, living in a populous district around Sousse were monitored by 3 general practitioners and 1 paediatrician. Samples were also collected from 155 healthy paediatric patients who were attending for vaccination. A swab was applied over both tonsils and the posterior pharynx and was transferred to the Microbiology Laboratory of Farhat Hached Hospital as soon as possible (2 to 3 hours after sampling). Samples were collected from patients before any antibiotic therapy.

All swabs were inoculated onto 5\% horse blood agar plates, with nalidixic acid and colistin and incubated in a $\mathrm{CO}_{2}$-enriched atmosphere for 24 hours at $37^{\circ} \mathrm{C}$. The cultures negative for beta-haemolytic streptococci were incubated during 24 hours under the same conditions. The positive beta-haemolytic colonies were isolated and applied to a $0.04 \mathrm{U}$ bacitracin disk, the halo was measured and the strains were identified by latex agglutination (Streptokit, bioMérieux, France). Forty-three (43) strains of group A streptococci isolated from the patients were serotyped by standard methods [13] at the Institut Für Experimentelle Mikrobiologie, Jena, Germany. The biotypes were determined with a commercially available identification system (rapid ID 32 STREP, bioMérieux, France), using the classification of Bouvet et al. [14].

Statistical analysis was carried out using chi-squared tests.

البحلة الصحية لشرق المتو سط، منظمة الصحة العالمية، البحلد العاشر، العددان ع-0، ع • • 


\section{Results}

Streptococcal strains were found in $12.9 \%$ of the controls and $20.7 \%$ of the patients. Group A streptococci had a frequency of $9.0 \%$ and $17.7 \%$ in the controls and the patients respectively (significant difference, $P<0.05$ ) (Table 1 ).

The isolation rates of group A streptococci peaked twice during the year from October to December and in June (Figure $1)$.
Of the 43 strains analysed, 93.0\% were typeable. Fifteen different types were identified, the most common being M75 (32.5\% of strains), M9 (14.0\%), M76 (11.6\%), and M12 (9.3\%) (Figure 2). The remaining serotypes ( $<3 \%$ each) were: M1, M14, M25, M2, M3, M11, M28, M8 and M49. Only 3 strains (7.0\%) were nontypeable.

Three biotypes were predominant: biotype 3, biotype 2 and biotype 1 (Table 2).

Table 1 Throat swab culture results in patients with acute pharyngitis and healthy controls

\begin{tabular}{lccccccc}
\hline Patient group & $\begin{array}{c}\text { No. of } \\
\text { patients }\end{array}$ & \multicolumn{2}{c}{$\begin{array}{c}\text { Group A } \\
\text { streptococci } \\
\text { No. of }\end{array}$} & \multicolumn{2}{c}{$\begin{array}{c}\text { Group C, G, F } \\
\text { streptococci } \\
\text { strains }\end{array}$} & $\begin{array}{l}\text { No. of } \\
\text { strains }\end{array}$ & \multicolumn{2}{c}{$\begin{array}{c}\text { Positive culture } \\
\text { strains }\end{array}$} & $\%$ \\
\hline Acute pharyngitis & 474 & 84 & 17.7 & 14 & 3.0 & 98 & 20.7 \\
Controls (carrier state) & 155 & 14 & 9.0 & 6 & 3.9 & 20 & 12.9 \\
\hline
\end{tabular}

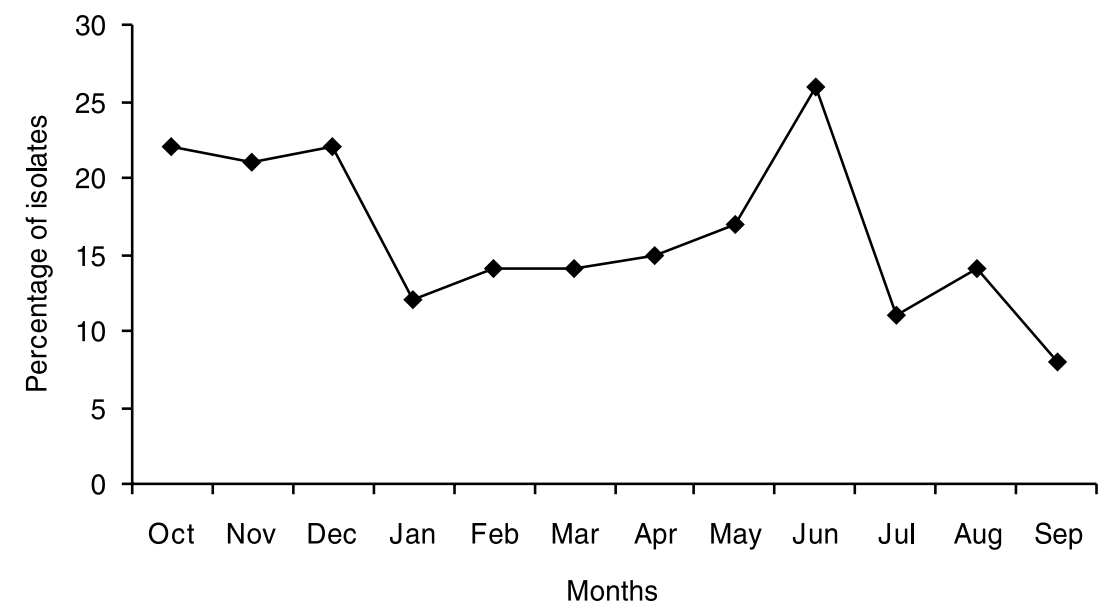

Figure 1 Monthly isolation rates of group A streptococci in patients with pharyngitis

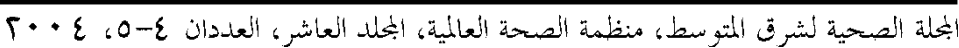




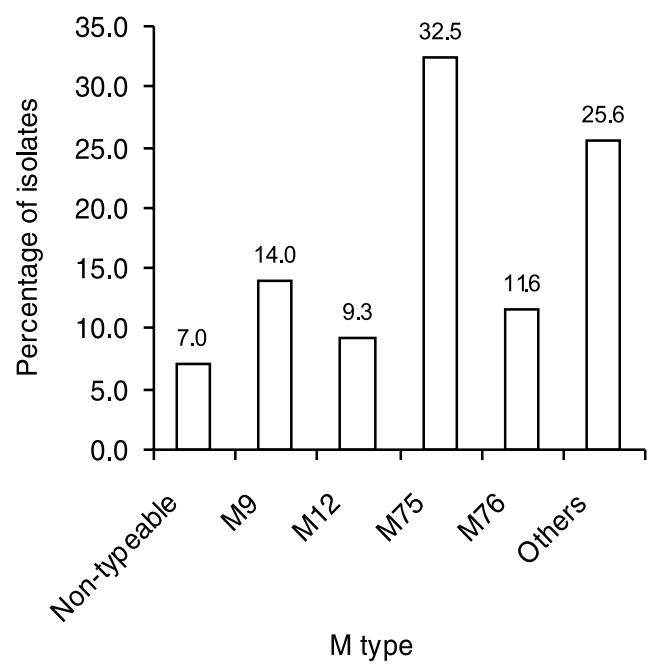

Figure 2 Distribution of $M$ types of group $A$ streptococci associated with acute pharyngitis ( $n=43$ strains)

\section{Discussion}

Little is known about the group A streptococci serotypes circulating in the Maghreb area and North Africa. To the best of our knowledge, the present study is the first Tunisian report of the serotypes of group A streptococci isolated from children with pharyngitis.

M serotyping might not adequately reflect the clonal diversity of bacterial strains, as suggested by the finding that

\begin{tabular}{|c|c|c|c|c|c|c|c|}
\hline \multicolumn{8}{|c|}{$\begin{array}{l}\text { Table } 2 \text { Biotype distribution of group A } \\
\text { streptococci associated with acute } \\
\text { pharyngitis ( } n=43 \text { strains) }\end{array}$} \\
\hline Biotype & 1 & 2 & 3 & 4 & 5 & 8 & 10 \\
\hline No. of strains & 7 & 11 & 14 & 5 & 4 & 1 & 1 \\
\hline
\end{tabular}

isolates expressing the same $M$ serotype can be distinguished by genetic methods [15-17]. Our results suggest that streptococcal pharyngitis is caused by a wide variety of strains, although 4 serotypes predominated (M75, M9, M76 and M12). Continued study may help define the epidemiology of group A streptococci in Tunisia.

Most isolates of group A streptococci described in developing countries, especially in the Middle East region, are untypeable $[7,18]$. Among typeable strains, $M$ type 1 is usually one of the predominant serotypes, as it was reported in Kuwait [7], Islamic Republic of Iran [18], and the United Arab Emirates [19].

In contrast, the high rate of typeable isolates in our study (93.0\%) suggests that group A streptococci strains in our city are similar but not necessarily related to those commonly found in Europe and North America. Furthermore, our findings highlight the low rate $(<3 \%)$ of $M$ type 1 , which has been associated with serious diseases such as rheumatic fever, a recognized problem in Tunisia, and toxic shock syndrome $[9,20]$, which has not yet been reported from our area.

Although the number of isolates was not sufficient to make any epidemiological conclusions, this data could be useful for further understanding the epidemiology of group A streptococcal infections, and for the development and use of a vaccine.

\section{Acknowledgements}

This work was supported by the Tunisian Ministry of Scientific Research. We thank Drs E. Günther and E. Straube (Institut Für experimentelle Mikrobiologie, Jena, Germany) for their help in serotyping the strains.

بلملة الصحية لشرق المثونط، منظمة الصحة العالمية، البحلد العاشر، العلدان ع-ه، ع + • 


\section{References}

1. Bisno AL. Group streptococcal infections and acute rheumatic fever. New England journal of medicine, 1991, 325:783-93.

2. Bach JF et al. 10-year educational programme aimed at rheumatic fever in two French Caribbean islands. Lancet, 1996, 347:644-8.

3. Markowitz M, Gerber MA, Kaplan EL. Treatment of streptococcal pharyngotonsillitis: reports of penicillin's demise are premature. Journal of pediatrics, 1993, 123:679-85.

4. Massel BF et al. Penicillin and the marked decrease in morbidity and mortality from rheumatic fever in the United States. New England journal of medicine, 1988, 318:280-6.

5. Veasy LG et al. Resurgence of acute rheumatic fever in the intermountain area of the United States. New England journal of medicine, 1987, 316:421-7.

6. Kaplan EL, Wotton JT, Johnson DR. Dynamic epidemiology of group A streptococcal serotypes associated with pharyngitis. Lancet, 2002, 358:1334-7.

7. Majeed HA et al. The concurrent associations of group A streptococcal serotypes in children with acute rheumatic fever or pharyngitis-associated glomerulonephritis and their families in Kuwait. Zentralblatt für Bakteriologie, Mikrobiologie, und Hygiene. Series $A$, 1986, 262:346-56.

8. Bryant AE, Hayes-Schroer SM, Stevens DL. M type 1 and 3 group A streptococci stimulate tissue factor-mediated procoagulant activity in human monocytes and endothelial cells. Infection and immunity, 2003, 71:1903-10.

9. Schwartz B, Facklam RR, Breiman RF. Changing epidemiology of group $A$ streptococcal infection in the USA. Lancet, 1990, 336:1167-71.
10. Stollerman GH. Rheumatic group $A$ streptococci and the return of rheumatic fever. Archives of internal medicine, 1990, 35:1-26.

11. Olive $C$ et al. Protection of mice from Group A streptococcal infection by intranasal immunisation with a peptide vaccine that contains a conserved $\mathrm{M}$ protein $B$ cell epitope and lacks a T cell epitope. Vaccine, 2002, 20:2816-25.

12. Bulletin épidémiologique. Direction des soins de santé de base. Tunis, Ministère de la Santé Publique, 2001.

13. Johnson DR et al. Laboratory diagnosis of group A streptococcal infections. Geneva, World Health Organization, 1997.

14. Bouvet A et al. Restricted association between biotypes and serotypes within group A streptococci. Journal of clinical microbiology, 1994, 32:1312-7.

15. Muotiala $A$ et al. Molecular comparison of group A streptococci of T1M1 serotype from invasive and non invasive infections in Finland. Journal of infectious diseases, 1997, 175:392-9.

16. Nguyen $L$ et al. Molecular epidemiology of streptococcus pyogenes in an area where acute pharyngotonsillitis is endemic. Journal of clinical microbiology, 1997, 35:2111-4.

17. Murase T et al. Characteristics of Streptococcus pyogenes serotype M1 and M3 isolates from patients in Japan from 1981 to 1997 . Journal of clinical microbiology, 1999, 37:4131-34.

18. Fazeli MR et al. Group A streptococcal serotypes isolated from healthy school children in Iran. European journal of clinical microbiology and infectious diseases, 2003, 22:475-8. 
19. Ameen AS et al. Serotypes of group A streptococci isolated from healthy schoolchildren in the United Arab Emirates. Bulletin of the World Health Organization, 1997, 75(4):355-9.

20. Johnson DR, Stevens DL, Kaplan EL. Epidemiologic analysis of group A strep- tococcal serotypes associated with severe systemic infections, rheumatic fever, or uncomplicated pharyngitis. Journal of infectious diseases, 1992, 166:374-82.

\section{Correction}

Knowledge, attitudes and practices survey among health care workers and tuberculosis patients in Iraq. D.S. Hashim, W. Al Kubaisy and A. Al Dulayme. Eastern Mediterranean Health Journal, 2003, Vol. 9 No. 4, pages 718-31.

The authors' names in Arabic should read:

$$
\text { عايل مو حان منعم الندليمي }
$$

The affiliation of Professor Al Kubaisy should read: College of Medicine, Al Nahrain University, Baghdad, Iraq.

Active tuberculosis among Iraqi schoolchildren with positive skin tests and their household contacts. W. Al Kubaisy, A. Al Dulayme and D.S. Hashim. Eastern Mediterranean Health Journal, 2003, Vol. 9 No. 4, pages 675-88.

The authors' names in Arabic should read:

$$
\text { وقار الكبيسي، عايل مو حان منعه اللديمي، ظافرسلمان هاشم }
$$

The affiliation of Professor Al Kubaisy should read: College of Medicine, Al Nahrain University, Baghdad, Iraq.

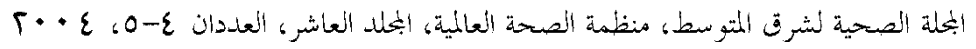

